\title{
The $\mathrm{PNH}_{3}$ of Renal Tubular Cells*
}

\author{
Gustave Denis, $\dagger$ Harry Precss, $+\frac{+}{\dagger}$ and Robert Pitts \\ (From the Department of Physiology, Cornell University Medical College, New York, N. Y.)
}

Ammonia is formed in tubular cells from precursors brought to the kidney in arterial blood (1-5). This ammonia diffuses passively as the free base into acid urine, where it is trapped as ammonium ion, and into peritubular capillaries, where it is rapidly removed into the general circulation (6-9). Under most circumstances, the concentration of ammonia in renal venous blood exceeds that in arterial blood. Thus ammonia has diffused from cells into peritubular blood as well as into urine. However, when ammonia is infused intravenously to elevate the arterial concentration significantly, the gradient reverses; the concentration of ammonia in renal venous blood is less than that in arterial blood $(10,11)$. Thus ammonia has diffused from peritubular blood across tubular cells into urine.

The fact that the diffusion of ammonia occurs from cells to renal venous blood under normal conditions and in the reverse direction when the arterial ammonia concentration is elevated implies that there must exist a blood concentration at which ammonia does not diffuse in either direction. The blood perfusing the kidney neither gains nor loses ammonia; the arterial and renal venous concentrations are equal. Under such circumstances the concentration of free base ammonia in renal venous blood is a mean of that of the population of tubular cells.

One may express the concentration of free base ammonia in either of two ways: in terms of micromoles, calculated from blood $\mathrm{pH}$ and total ammonia concentration (free base plus ammonium ion) by the Henderson-Hasselbalch equation, or as $\mathrm{PNH}_{3}$ in $\mathrm{mm} \mathrm{Hg}$, by an added step involving the use of the Bunsen coefficient. Because we believe that a diffusion gradient for the gas, $\mathrm{NH}_{3}$,

* Submitted for publication August 15, 1963 ; accepted November 21, 1963.

Supported by research grants from the National Heart Institute and the Life Insurance Medical Research Fund.

$\dagger$ Research trainee, National Heart Institute.

$\$$ Fellow of the U. S. Public Health Service. is best expressed in terms of partial pressure, we have calculated $\mathrm{PNH}_{3}$, using the formula of Jacquez, Poppell, and Jeltsch (12). Use of either expression implies that only the free base diffuses in appreciable amounts across cell membranes and that diffusion, not active secretion, accounts for the movement of ammonia into both urine and peritubular blood. Values of $\mathrm{PNH}_{3}$ that we have observed are of the same order of magnitude as those observed by Bromberg, Robin, and Forkner (13).

As a consequence of our studies on the intravenous infusion of ammonium lactate in dogs we have reached the following conclusions. 1) Tubular cells and peritubular blood are in diffusion equilibrium with respect to free base ammonia. Therefore, the $\mathrm{PNH}_{3}$ of renal venous blood approximates that of tubular cells. 2) Since the major fraction of the renal arterial inflow perfuses the cortex of the kidney, the $\mathrm{PNH}_{3}$ of the renal venous blood must be largely determined by that of cells of proximal and distal convoluted tubules. 3) The $\mathrm{PNH}_{3}$ of tubular cells is determined by the balance of a number of factors including rate of production of ammonia, $\mathrm{pH}$ of tubular cells, and $\mathrm{pH}$ and rate of flow of tubular urine.

\section{Methods}

Thirty-seven experiments have been performed on mongrel dogs of either sex, anesthetized by the iv administration of $30 \mathrm{mg}$ per $\mathrm{kg}$ or less of pentobarbital. Additional small doses of the anesthetic were given as needed; an attempt was made to avoid undue depression of respiration with its attendent increase of arterial $\mathrm{PCO}_{2}$ and decrease of arterial $\mathrm{pH}$. The bladder was exposed through a mid-line incision just above the symphysis pubis, and a catheter was passed into each ureter to a level estimated to be just below the renal pelvis. A radiopaque catheter was introduced into the vena cava through an incision in the femoral vein and maneuvered into the right renal vein under fluoroscopic observation. Its position was checked by a quick determination of extraction of para-aminohippurate (PAH) and was verified at autopsy. A needle with a tight fit- 
ting stylet was inserted into the femoral artery percutaneously. Samples of arterial and renal venous blood were collected simultaneously at the mid-point of each urine collection period.

Blood for ammonia determination was drawn into lightly oiled, heparinized, $20-\mathrm{ml}$ syringes, containing $5 \mathrm{ml}$ of $100 \%$ carbon dioxide. The syringes were capped and plunged into shaved ice. Analyses were performed in duplicate or triplicate on 5-ml samples of whole blood by the method of Archibald (14). A second sample of blood was drawn for the determination of plasma concentrations of creatinine (15) and PAH (16). A third sample was collected anaerobically for the determination of blood $\mathrm{pH}$ and plasma carbon dioxide content (17). Blood $\mathrm{pH}$ was measured at $38^{\circ} \mathrm{C}$ using a RadiometerCopenhagen meter and a microglass electrode. The $\mathrm{PNH}_{3}$ of arterial and renal venous blood samples has been calculated from total ammonia concentration and $\mathrm{pH}$ by the method of Jacquez and associates (12). Ideally plasma ammonia should have been measured and plasma $\mathrm{PNH}_{3}$ calculated. However, since plasma and whole blood total ammonias differed by an amount scarcely greater than the experimental error of the determinations, ${ }^{1}$ whole blood values were measured routinely.

${ }^{1}$ In four experiments, total ammonia concentrations of whole blood and of plasma of arterial and renal venous samples were compared. Whole blood concentrations averaged $8 \%$ less than those of plasma; the percentage differences were smaller the higher the concentrations. One would expect the reverse, namely, whole blood concentrations should be higher than plasma values, for the $\mathrm{pH}$ of the content of the red cell is less than that of plasma. However, the water content of whole blood is less than that of plasma, a factor that would tend to reduce difference in distribution. We elected to measure whole blood ammonia concentration for three reasons: 1) whole blood values remained stable, when the blood was iced and maintained in contact with $100 \%$ carbon dioxide, for as long as 6 hours; plasma values did not; 2) whole blood values were lower, a fact which led us to believe that our plasma ammonias
The creatinine clearance has been used as a measure of glomerular filtration rate, and the true renal plasma flow has been calculated from extraction and excretion of PAH by the formula of Wolf (18). Blood flow was calculated from renal plasma flow and hematocrit. In calculating arterial-renal venous differences of ammonia, the venous value has been corrected for the slight degree of concentration that results from the removal of water in the urine. The product of renal blood flow and the corrected arteriovenous (a-v) difference for ammonia yields the quantity of ammonia added to or subtracted from the blood per minute. The rate of excretion of ammonia plus that added to or subtracted from the renal venous blood equals the rate of production of ammonia. Urine ammonias were measured by the microdiffusion procedure of Conway (19). Creatinine and $\mathrm{PAH}$ were administered by intravenous infusion in amounts sufficient to maintain plasma concentrations of 20 and $1.0 \mathrm{mg}$ per $100 \mathrm{ml}$, respectively. The infusion, made two-thirds isotonic with sodium sulfate, was given at a rate of $5 \mathrm{ml}$ per minute in all experiments other than those in metabolic alkalosis. In these bicarbonate was substituted for sulfate.

\section{Results}

Table I and Figure 1 summarize results obtained in one of a series of experiments which suggest that the $\mathrm{PNH}_{3}$ of renal venous blood is essentially equal to that of tubular cells. The dog had been given $10 \mathrm{~g}$ of ammonium chloride each day for 3 days, mixed with the food, to induce metabolic acidosis and to acidify the urine. On the day of the experiment the right ureter was catheterized, and a radiopaque catheter was introduced into

were artificially high due to liberation of ammonia at some stage in preparation or storage before analysis; 3 ) the differences between whole blood and plasma were scarcely more than the error of determination.

TABLE I

The effect of the infusion of ammonium lactate on arterial and renal venous $\mathrm{PNH}_{3}$ in a dog in chronic metabolic acidosis

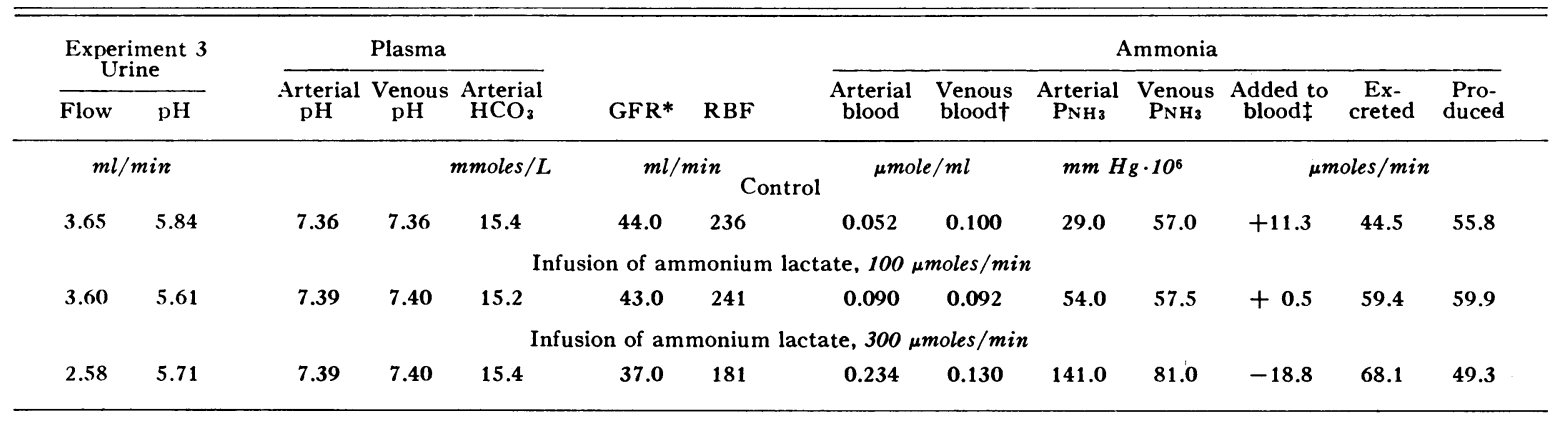

* GFR, glomerular filtration rate; RBF, renal blood flow.

t Renal venous ammonia concentration corrected for the renal excretion of water.

$\ddagger$ Positive values indicate amounts of ammonia added to renal blood; negative values indicate amounts of ammonia extracted from renal blood. 


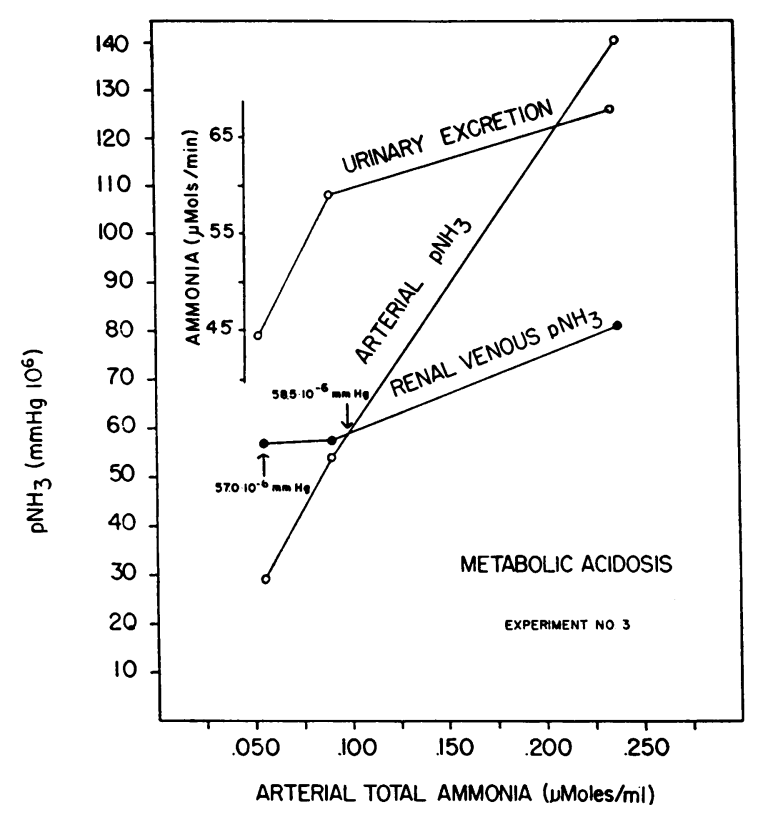

Fig. 1. The Relationships among arterial and RENAL veNOUS $\mathrm{PNH}_{3}$, AMMONIA EXCRETION, AND ARTERIAL AMMONIA CONCENTRATION IN A DOG IN CHRONIC METABOLIC ACIDOSIS. The arterial ammonia concentration was increased by the infusion of ammonium lactate at rates of 100 and $300 \mu$ moles per minute. See Table I for complete data.

the right renal vein. All data are from the right kidney only.

In the control series of observations, shown on the left of Figure 1, the arterial ammonia concentration was $0.052 \mu$ mole per $\mathrm{ml}$ of blood. The arterial $\mathrm{PNH}_{3}$, an expression of the diffusing tendency of the free base, was calculated to be $29 \times 10^{-6} \mathrm{~mm} \mathrm{Hg}$. The renal venous $\mathrm{PNH}_{3}$ was significantly higher, namely $57 \times 10^{-6} \mathrm{~mm} \mathrm{Hg}$, owing largely to its greater ammonia concentration, since the renal venous $\mathrm{pH}$ was essentially the same as the arterial value (see Table I). As blood perfused the kidney, ammonia diffused from tubular cells into peritubular capillaries increasing the $\mathrm{PNH}_{3}$ from $29 \times 10^{-6} \mathrm{~mm} \mathrm{Hg}$ to $57 \times 10^{-6} \mathrm{~mm} \mathrm{Hg}$. During this period the rate of excretion of ammonia was $44.5 \mu$ moles per minute.

During the second period ammonium lactate was infused at a rate of $100 \mu$ moles per minute, sufficient to raise the arterial ammonia concentration to $0.090 \mu$ mole per $\mathrm{ml}$ and the arterial $\mathrm{PNH}_{3}$ to $54 \times 10^{-6} \mathrm{~mm} \mathrm{Hg}$. The renal venous $\mathrm{PNH}_{3}$ remained nearly the same, $57.5 \mathrm{~mm} \mathrm{Hg}$.
Since the diffusion gradient was to all intents abolished, very little ammonia was added to renal venous blood. Instead, the ammonia which had been added to renal venous blood was now diverted into the urine, increasing the rate of excretion from 45 to $59 \mu$ moles per minute.

In the third period, ammonium lactate was infused at a rate of $300 \mu$ moles per minute. The arterial ammonia concentration rose to $0.234 \mu$ mole per $\mathrm{ml}$ and the arterial $\mathrm{PNH}_{3}$ to $141 \times 10^{-6} \mathrm{~mm}$ $\mathrm{Hg}$. The diffusion gradient was now reversed; the venous $\mathrm{PNH}_{3}$ was $81 \times 10^{-6} \mathrm{~mm} \mathrm{Hg}$, and ammonia diffused from arterial blood into tubular cells and then into the urine. Accordingly, the rate of excretion of ammonia was further increased to $68 \mu$ moles per minute, the sum of that which was produced in cells and that which diffused into the urine from the peritubular blood.

At the point of intersection of the arterial and renal venous $\mathrm{PNH}_{3}$ lines, namely, $58.5 \times 10^{-6}$ $\mathrm{mm} \mathrm{Hg}$, no ammonia diffused from tubular cells into peritubular blood, and none diffused from peritubular blood into cells. Therefore, this $\mathrm{PNH}_{3}$ must represent that of tubular cells. The value of $58.5 \times 10^{-6} \mathrm{~mm} \mathrm{Hg}$ obviously does not represent cell $\mathrm{PNH}_{3}$ under control conditions, i.e., in the absence of the infusion of ammonia,

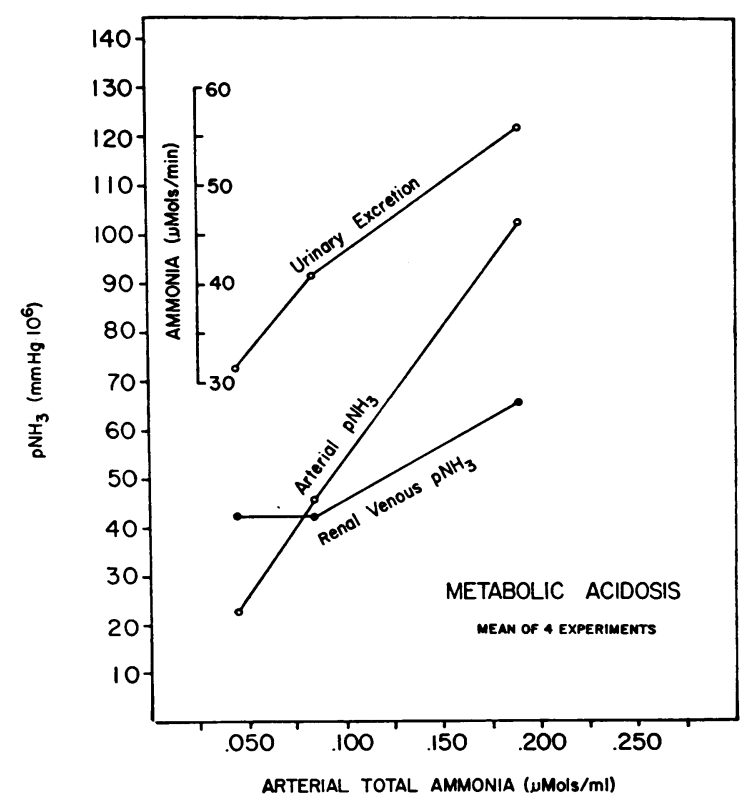

Fig. 2. SumMary OF Four EXPeriments Similar to the one presented in Figure 1 and Table I. Mean values and ranges are presented in Table II. 
TABLE II

Arterial and renal venous ammonia concentrations and $\mathrm{PNH}_{3}$ values and rates of ammonia excretion in four experiments in chronic metabolic acidosis

\begin{tabular}{|c|c|c|c|c|c|c|}
\hline \multirow{2}{*}{$\begin{array}{l}\text { Rate of infusion of } \\
\text { ammonium lactate, } \\
\mu \text { moles } / \min \end{array}$} & \multicolumn{2}{|r|}{0} & \multicolumn{2}{|r|}{100} & \multicolumn{2}{|r|}{300} \\
\hline & Mean & Range & Mean & Range & Mean & Range \\
\hline $\begin{array}{l}\text { Arterial ammonia, } \\
\quad \mu m o l e / m l\end{array}$ & 0.041 & $0.034-0.052$ & 0.083 & $0.054-0.098$ & 0.172 & $0.134-0.234$ \\
\hline $\begin{array}{l}\text { Arterial } \mathrm{PNH}_{3}, \\
\qquad m m \mathrm{Hg} \times 10^{6} .\end{array}$ & 22.4 & $15.8-29.0$ & 45.7 & $26.0-54.0$ & 103 & $64.0-141$ \\
\hline $\begin{array}{l}\text { Renal venous ammonia, } \\
\quad \mu m o l e / m l\end{array}$ & 0.079 & $0.068-0.100$ & 0.079 & $0.066-0.092$ & 0.121 & $0.093-0.135$ \\
\hline $\begin{array}{l}\text { Renal venous } \mathrm{PNH}_{3} \\
m m H g \times 10^{6}\end{array}$ & 42.3 & $32.2-57.0$ & 42.2 & $33.0-57.5$ & 66.1 & $43.5-81.0$ \\
\hline $\begin{array}{l}\text { Ammonia excretion, } \\
\mu \text { moles } / \min \end{array}$ & 31.2 & $14.6-44.5$ & 41.2 & $22.8-59.4$ & 56.0 & $47.0-68.0$ \\
\hline
\end{tabular}

for the urinary excretion of ammonia had increased significantly. However, tubular cell $\mathrm{PNH}_{3}$ cannot be less than the venous value in the control period, namely $57 \times 10^{-6} \mathrm{~mm} \mathrm{Hg}$. The difference between the control venous value and the venous value at the point of intersection is less than $3 \%$. Accordingly, as a first approximation, the control venous value can be accepted as a measure of tubular cell $\mathrm{PNH}_{3}$ under control conditions.

Average values obtained in a series of four identical experiments are presented in Figure 2. The mean difference between the control renal venous $\mathrm{PNH}_{3}$ and that at which the venous and arterial lines intersect is less than $1 \times 10^{-6} \mathrm{~mm}$ $\mathrm{Hg}$, a value well within the limits of experimental error of the determination. The ranges of blood concentrations, $\mathrm{PNH}_{3}$ values, and rates of excretion in these four experiments are given in Table II. In essence these experiments have demonstrated in acidotic animals that diffusion equilib- rium is attained between tubular cells and renal venous blood and that the $\mathrm{PNH}_{3}$ of renal venous blood can be accepted as an approximation of tubular cell $\mathrm{PNH}_{3}$.

In animals in metabolic alkalosis excreting alkaline urine, the response to the infusion of ammonium lactate is different. The renal venous $\mathrm{PNH}_{3}$ exceeds the arterial $\mathrm{PNH}_{3}$ at all concentrations studied. One such experiment is summarized in Table III and Figure 3. Sodium bicarbonate was infused throughout the experiment to induce an acute metabolic alkalosis and to maintain the urine alkaline.

In the control series of observations, shown on the left of Figure 3, the arterial ammonia concentration was $0.040 \mu$ mole per $\mathrm{ml}$, and the arterial $\mathrm{PNH}_{3}$ was $34.5 \times 10^{-6} \mathrm{~mm} \mathrm{Hg}$. The renal venous ammonia concentration and $\mathrm{PNH}_{3}$ exceeded the arterial values, i.e., ammonia was added to the peritubular blood in alkalosis as well as in

TABLE III

The effect of the infusion of ammonium lactate on arterial and renal venous $\mathrm{PNH}_{3}$ in a dog in chronic metabolic alkalosis

\begin{tabular}{|c|c|c|c|c|c|c|c|c|c|c|c|c|c|}
\hline \multicolumn{2}{|c|}{$\begin{array}{c}\text { Experiment } 11 \\
\text { Urine }\end{array}$} & \multicolumn{3}{|c|}{ Plasma } & \multirow[b]{2}{*}{ GFR* } & \multirow[b]{2}{*}{ RBF } & \multicolumn{7}{|c|}{ Ammonia } \\
\hline Flow & $\frac{\mathrm{pH}}{\mathrm{pH}}$ & $\begin{array}{l}\text { Arterial } \\
\text { pH }\end{array}$ & $\begin{array}{c}\text { Venous } \\
\text { pH }\end{array}$ & $\underset{\mathrm{HCO}_{3}}{\text { Arterial }}$ & & & $\begin{array}{c}\text { Arterial } \\
\text { blood }\end{array}$ & $\begin{array}{l}\text { Venous } \\
\text { bloodt }\end{array}$ & $\begin{array}{c}\text { Arterial } \\
\text { PNH3 }\end{array}$ & $\begin{array}{c}\text { Venous } \\
\mathrm{PNH}_{3}\end{array}$ & $\begin{array}{c}\text { Added to } \\
\text { blood } \ddagger\end{array}$ & $\begin{array}{c}\text { Ex- } \\
\text { creted }\end{array}$ & $\begin{array}{l}\text { Pro- } \\
\text { duced }\end{array}$ \\
\hline \multicolumn{2}{|c|}{$\mathrm{ml} / \mathrm{min}$} & & & \multirow[t]{2}{*}{ mmoles $/ L$} & \multicolumn{2}{|c|}{$m l / m i n$} & \multicolumn{2}{|c|}{$\mu m o l e / m l$} & \multicolumn{2}{|c|}{$m m \mathrm{Hg} \cdot 10^{6}$} & \multicolumn{3}{|c|}{ $\mu$ moles $/ \mathrm{min}$} \\
\hline \multicolumn{13}{|c|}{ Control } & \\
\hline 1.36 & 8.21 & 7.55 & 7.54 & 30.2 & 38.1 & 196 & 0.040 & 0.085 & 34.5 & 72.5 & +8.8 & 0.5 & 9.3 \\
\hline \multicolumn{14}{|c|}{ Infusion of ammonium lactate, $100 \mu$ moles $/ \mathrm{min}$} \\
\hline 1.50 & 7.96 & 7.56 & 7.55 & 32.8 & 35.5 & 194 & 0.106 & 0.121 & 93.5 & 104.0 & +2.9 & 1.4 & 4.3 \\
\hline \multicolumn{14}{|c|}{ Infusion of ammonium lactate, $300 \mu \mathrm{moles} / \mathrm{min}$} \\
\hline 2.55 & 8.05 & 7.57 & 7.56 & 31.0 & 32.8 & 192 & 0.238 & 0.240 & 214 & 214.0 & +0.4 & 2.0 & 2.4 \\
\hline
\end{tabular}

$*, \dagger, \ddagger$ See Table I. 


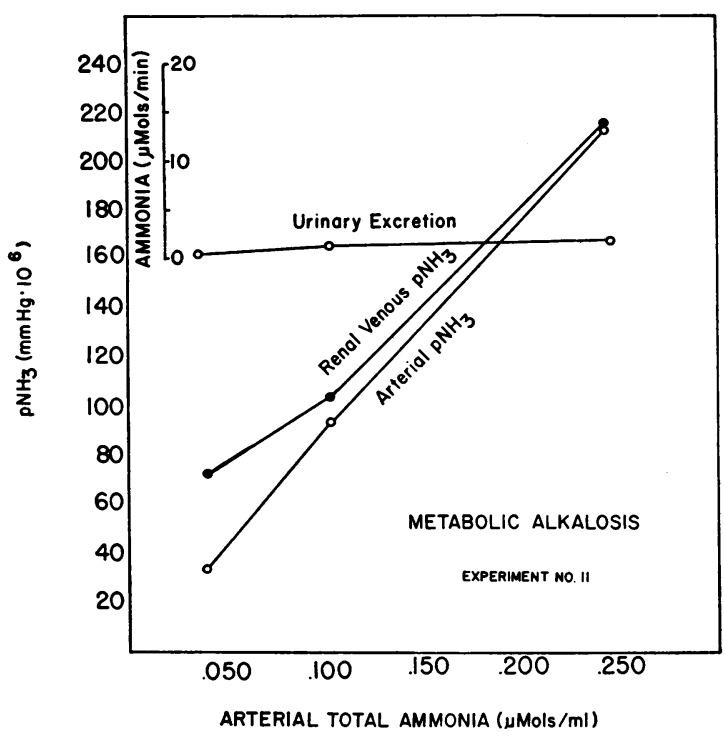

Fig. 3. The RELAtionships among arterial AND RENAL VENOUS $\mathrm{PNH}_{3}$, AMMONIA EXCRETION, AND ARTERIAL AMMONIA CONCENTRATION IN A DOG IN CHRONIC METABOLIC ALKaLosis. The arterial ammonia concentration was increased by the infusion of ammonium lactate of rates of 100 and $300 \mu$ moles per minute. See Table III for complete data.

acidosis. However, the rate of excretion of ammonia was quite low, only $0.5 \mu$ mole per minute. The infusion of ammonium lactate at rates of 100 and $300 \mu$ moles per minute elevated both arterial and renal venous ammonia concentrations and $\mathrm{PNH}_{3}$ values more or less proportionally. Each increment in arterial ammonia concentration resulted in an essentially equal increment in renal venous concentration. The elevation of arterial $\mathrm{PNH}_{3}$ resulted only in increased tubular cell $\mathrm{PNH}_{3}$ and renal venous $\mathrm{PNH}_{3}$, not in any significant

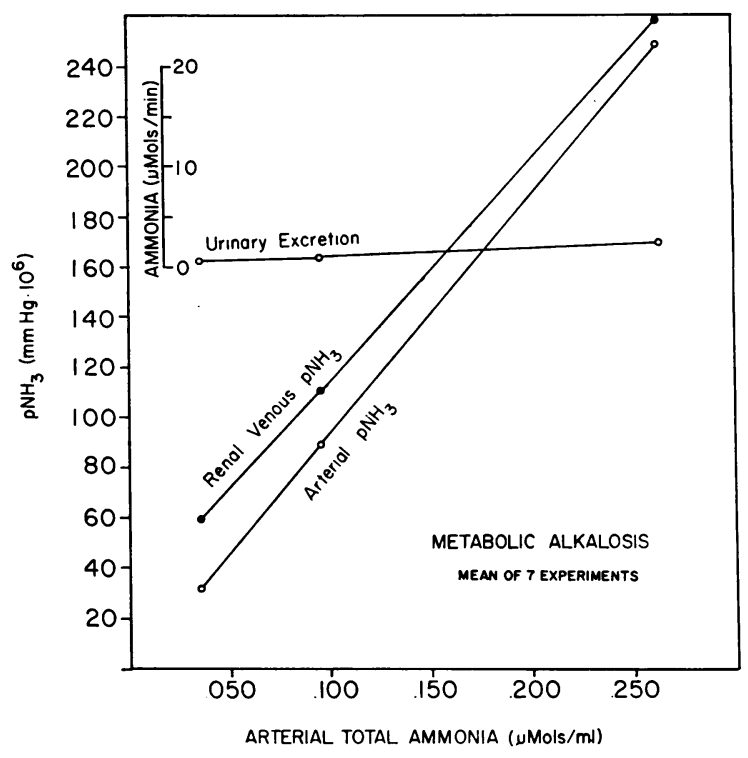

Fig. 4. Summary of SEven EXPeriments Similar to the one presented in Figure 3 and Table III. Mean values and ranges are presented in Table IV.

increase in excretion. The filtered ammonia in large part must have diffused back into peritubular blood. Although urine $\mathrm{pH}$ and blood $\mathrm{pH}$ were essentially the same, the greater volume flow of blood would favor diffusion of ammonia from tubular lumen to peritubular capillaries. If diffusion equilibrium is attained between tubular cells and peritubular blood in acidosis, there is no reason to believe that it is not attained in alkalosis, although it is impossible to demonstrate that fact.

Average values obtained in a series of seven identical experiments in metabolic alkalosis are presented in Figure 4. The ranges of blood con-

TABLE IV

Arterial and renal venous ammonia concentrations and $\mathrm{PNH}_{3}$ values and rates of ammonia excretion in seven experiments in chronic metabolic alkalosis

\begin{tabular}{|c|c|c|c|c|c|c|}
\hline \multirow{2}{*}{$\begin{array}{l}\text { Rate of infusion of } \\
\text { ammonium lactate, } \\
\mu \text { moles } / \text { min }\end{array}$} & \multicolumn{2}{|r|}{0} & \multicolumn{2}{|r|}{100} & \multicolumn{2}{|r|}{300} \\
\hline & Mean & Range & Mean & Range & Mean & Range \\
\hline $\begin{array}{l}\text { Arterial ammonia, } \\
\mu m o l e / m l\end{array}$ & 0.034 & $0.014-0.056$ & 0.094 & $0.060-0.142$ & 0.260 & $0.192-0.340$ \\
\hline $\begin{array}{l}\text { Arterial } \mathrm{PNH}_{3} \\
\qquad m m \mathrm{Hg} \times 10^{6}\end{array}$ & 31.5 & $11.5-57.7$ & 89.0 & $65.5-157$ & 245 & $214-321$ \\
\hline $\begin{array}{l}\text { Renal venous ammonia, } \\
\mu m o l e / m l\end{array}$ & 0.066 & $0.046-0.085$ & 0.117 & $0.092-0.156$ & 0.268 & $0.192-0.359$ \\
\hline $\begin{array}{l}\text { Renal venous } \mathrm{PNH}_{3} \\
m m \mathrm{Hg} \times 10^{6}\end{array}$ & 59.7 & $37.0-78.3$ & 110 & $77.5-174$ & 252 & $184-324$ \\
\hline $\begin{array}{l}\text { Ammonia excretion, } \\
\mu \text { moles } / \text { min }\end{array}$ & 0.40 & $0.0-1.40$ & 0.90 & $0.60-1.40$ & 2.4 & $0.60-8.20$ \\
\hline
\end{tabular}




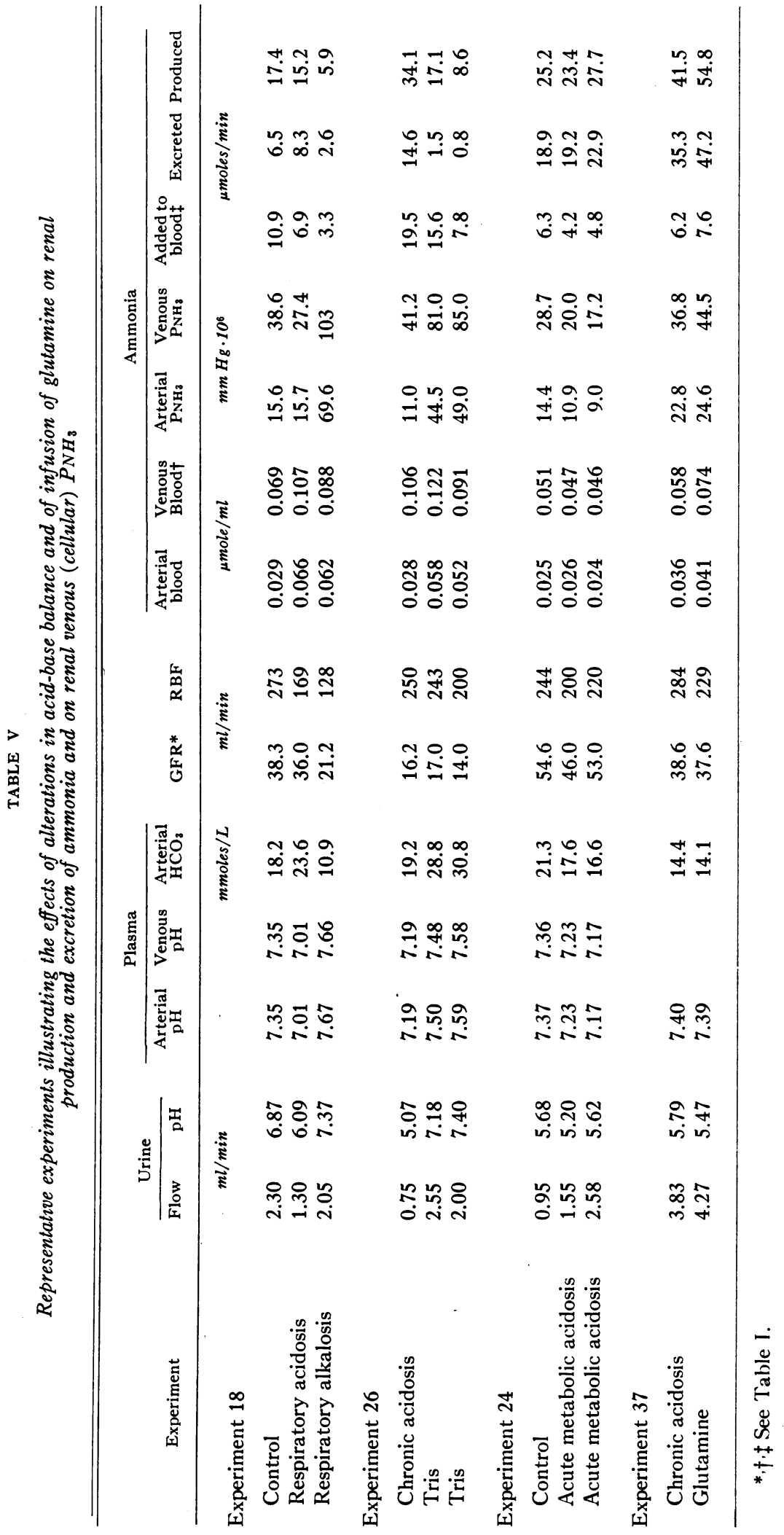


centrations, $\mathrm{PNH}_{3}$ values, and rates of excretion in these seven experiments are given in Table IV. Results are in accord with the thesis presented above.

If diffusion equilibrium for ammonia is attained between tubular cells and peritubular blood and if the renal venous $\mathrm{PNH}_{3}$ is a reasonable approximation of tubular cell $\mathrm{PNH}_{3}$, a valid question is: Which cells are implicated? According to Kramer, Thurau, and Deetjen (20), some $90 \%$ of the renal blood perfuses the cortex, $8 \%$ the outer medulla, and only $2 \%$ the papilla. If true, the $\mathrm{PNH}_{3}$ of blood in the peritubular capillaries of the cortex must largely determine the $\mathrm{PNH}_{3}$ of the renal venous effluent. In the cortex, convolutions of proximal and distal tubules are intermixed. We, therefore, believe that the $\mathrm{PNH}_{3}$ of renal venous blood is an approximation of the $\mathrm{PNH}_{3}$ of proximal and distal tubular cells. It may well be that diffusion equilibrium for ammonia exists among all phases in the renal cortex, namely, tubular cells, peritubular blood, and tubular urine. Such a view, which implies a large contribution of cortical elements to the renal production of ammonia, would be difficult to accept were it not that Glabman, Klose, and Giebisch (21) have shown in acidotic rats that half or more of the urinary ammonia is formed in proximal tubules. As yet we have been unable to devise a method by which we can estimate the $\mathrm{PNH}_{3}$ of cortical tubular urine.

If one is willing to accept the thesis that diffusion equilibrium for ammonia is attained between tubular cells and peritubular blood and that the $\mathrm{PNH}_{3}$ of renal venous blood is largely determined by the $\mathrm{PNH}_{3}$ of cells of cortical tubules, it is possible to study changes in $\mathrm{PNH}_{3}$ of these cells under a variety of conditions by the simple expedient of measuring renal venous $\mathrm{PNH}_{3}$. Data obtained in four representative experiments of this nature are presented in Table V, and summaries of all experiments are presented in Table VI.

Experiment 18, Table V, illustrates the effect of acute respiratory acidosis and alkalosis on renal ammonia excretion and production and on renal venous (cellular) $\mathrm{PNH}_{3}$. During the control period, the animal was in a state of mild metabolic acidosis, possibly in part dilutional in origin (plasma $\mathrm{HCO}_{3}=18.2$ mmoles per liter; $\mathrm{pH}=$
7.35). The inhalation of $20 \%$ carbon dioxide in oxygen by tracheal tube lowered plasma $\mathrm{pH}$ to 7.01 and increased plasma bicarbonate to 23.6 mmoles per L. Although arterial and renal venous ammonia concentrations both increased, renal venous (cellular) $\mathrm{PNH}_{3}$ fell. Changes in rate of excretion, in rate of addition to renal venous blood, and in rate of renal production of ammonia were all of minor proportions and of doubtful significance. These same findings are evident in Table VI, if one compares values of the three experiments in respiratory acidosis with their respective controls. In contrast, in respiratory alkalosis (Table V, Experiment 18, and Table VI) renal venous (cellular) $\mathrm{PNH}_{3}$ increased markedly despite significant decreases in rate of addition of ammonia to blood and rates of excretion and of production of ammonia. Cellular $\mathrm{PNH}_{3}$, therefore, fell in respiratory acidosis without significant change in production and increased in respiratory alkalosis despite marked reduction in production. In respiratory acidosis cellular $\mathrm{pH}$ falls, whereas in respiratory alkalosis it rises (22). At any given rate of production, therefore, cellular $\mathrm{PNH}_{3}$ should be directly related to cellular $\mathrm{pH}$, other factors remaining constant. Although an acute increase in cell $\mathrm{pH}$ reduces production, an acute reduction in $\mathrm{pH}$ does not increase production. Furthermore, changes in urine $\mathrm{pH}$ and blood $\mathrm{pH}$ in respiratory acidosis and alkalosis further complicate the problem by altering diffusion gradients.

In Experiment 26, Table V, and in Table VI Tris [tris (hydroxymethyl)aminomethane] was infused into an animal in chronic metabolic acidosis at rates varying from 160 to $200 \mu$ moles per minute. This base not only induces an extracellular alkalosis, but like hyperventilation induces an intracellular alkalosis as well (22). Renal venous (cellular) $\mathrm{PNH}_{3}$ increased markedly despite marked decreases in rates of excretion and of production of ammonia, results comparable to those observed in respiratory alkalosis.

Experiment 24, Table V, and Table VI illustrate the relatively minor renal responses to acute metabolic acidosis induced by the infusion of hydrochloric acid. Production of ammonia was essentially unchanged; the small increase in urinary excretion was nearly balanced by a decrease in the addition of ammonia to renal venous blood. 
TABLE VI

Summary of all experiments designed to test the relationships among renal

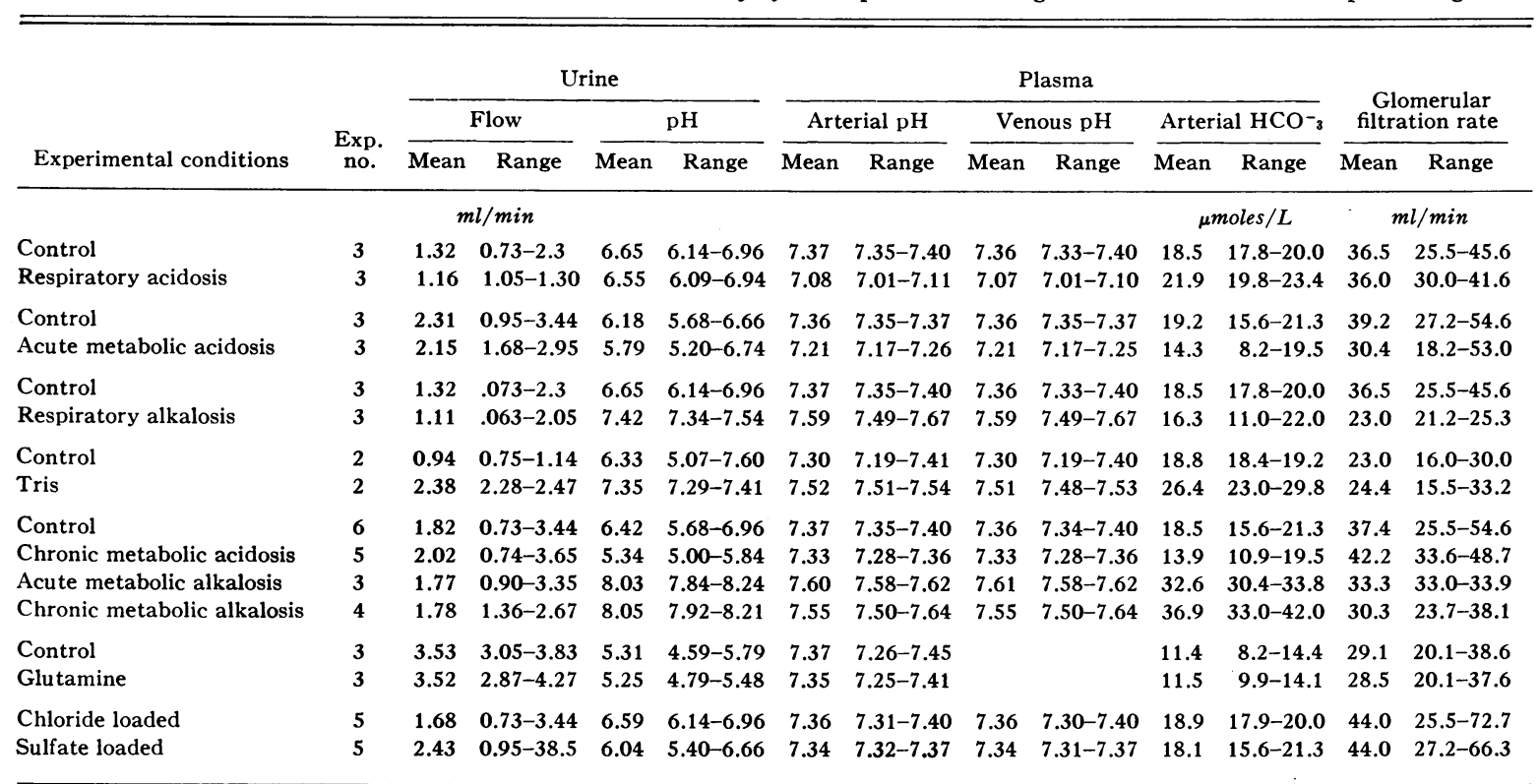

Renal venous (cellular) $\mathrm{PNH}_{3}$ was modestly reduced. Evidently both acute metabolic acidosis and acute respiratory acidosis have little effect on rate of production of ammonia and induce only a modest decrease in cellular $\mathrm{PNH}_{3}$. This latter fact is no doubt related to lower urine $\mathrm{pH}$, i.e., to a more marked diffusion "sink" for ammonia, evident in the mean values given in Table VI, although not in the single experiment of Table V.

In contrast, chronic metabolic acidosis (Table VI) induced a marked increase in rate of ammonia production, from $20.5 \mu$ moles per minute in control experiments ${ }^{2}$ to $44.4 \mu$ moles per minute in chronic acidosis, most of which was excreted in the urine. A small, probably insignificant, increase in the amount added to renal venous blood (from 9.7 to $11.0 \mu$ moles per minute) is evident. The renal venous (cellular) $\mathrm{PNH}_{3}$ increased to only a small extent (from 35 to 43.6 $\times 10^{-6} \mathrm{~mm} \mathrm{Hg}$ ). No doubt the reason for this modest increase in $\mathrm{PNH}_{3}$, despite a marked in-

\footnotetext{
2 Since all experiments were terminated by autopsy, control values for those on chronic metabolic acidosis were of necessity obtained in experiments on animals in normal acid-base balance. Chronic metabolic acidosis was induced by the administration in the food of $10 \mathrm{~g}$ of ammonium chloride each day for at least 3 days. Variations in degree of acidosis no doubt resulted from failure of some animals to ingest all of the food.
}

crease in rate of production, is rapid diffusion of ammonia into acid urine.

Experiment 37, Table V, and Table VI illustrate the renal responses of chronically acidotic animals to the intravenous infusion of glutamine at a rate of $150 \mu$ moles per minute. The production and excretion of ammonia increased significantly in association with a modest increase in renal venous (cellular) $\mathrm{PNH}_{3}$. Again, rapid diffusion into acid urine no doubt accounts for the small increase in cellular $\mathrm{PNH}_{3}$ despite the significant increase in rate of ammonia production.

The experiments in acute and chronic metabolic alkalosis (Table VI) differed only in the fact that in the latter, $10 \mathrm{~g}$ of sodium bicarbonate was given in the food each day for 3 days before the experiment. In both acute and chronic metabolic alkalosis, sodium bicarbonate was infused during the experiment to elevate plasma bicarbonate and to ensure the formation of alkaline urine. Urinary excretion of ammonia was very low, and production was much reduced. Renal venous (cellular) $\mathrm{PNH}_{3}$ was significantly increased in comparison with control values, ${ }^{3}$ yet was appreci-

3 The data in both acute and chronic metabolic alkalosis were obtained in experiments similar to the one illustrated in Table III and Figure 3. Sodium bicarbonate was infused throughout the course of these experi- 
TABLE VI

production and excretion of ammonia and renal venous (cellular) $\mathrm{PNH}_{3}$

\begin{tabular}{|c|c|c|c|c|c|c|c|c|c|c|c|c|c|c|c|}
\hline \multirow{2}{*}{\multicolumn{2}{|c|}{$\begin{array}{c}\text { Renal blood } \\
\text { flow }\end{array}$}} & \multicolumn{14}{|c|}{ Ammonia } \\
\hline & & \multicolumn{2}{|c|}{$\begin{array}{l}\text { Arterial con- } \\
\text { centration }\end{array}$} & \multicolumn{2}{|c|}{$\begin{array}{l}\text { Venous con- } \\
\text { centration }\end{array}$} & \multicolumn{2}{|c|}{ Arterial $\mathrm{PNH}_{3}$} & \multicolumn{2}{|c|}{ Venous $\mathrm{PNH}_{3}$} & \multicolumn{2}{|c|}{ Added to blood } & \multicolumn{2}{|c|}{ Excreted } & \multicolumn{2}{|c|}{ Produced } \\
\hline Mean & n Range & Mean & Range & Mean & Range & Mean & Range & Mean & Range & Mean & Range & Mean & Range & Mean & Range \\
\hline \multicolumn{2}{|c|}{$\mathrm{ml} / \mathrm{min}$} & \multicolumn{4}{|c|}{$\mu$ moles $/ \mathrm{ml}$} & \multicolumn{4}{|c|}{$m m \mathrm{Hg} \cdot 10^{6}$} & \multicolumn{6}{|c|}{ umoles/min } \\
\hline 272 & $209-336$ & .037 & $.029-.044$ & .081 & $.069-.094$ & 20.7 & $15.6-28.0$ & 44.2 & $38.6-51.0$ & 11.4 & $10.9-12.1$ & 8.2 & $4.6-13.6$ & 20.8 & $16.7-28.4$ \\
\hline 200 & $157-275$ & .052 & $.044-.066$ & .107 & $.106-.108$ & 12.9 & $9.3-15.6$ & 29.0 & $27.4-30.0$ & 11.0 & $7.1-16.5$ & 7.3 & $6.5-8.3$ & 18.3 & $15.4-23.0$ \\
\hline 254 & $214-303$ & .026 & $.024-.028$ & .056 & $.042-.075$ & 13.0 & $9.9-14.5$ & 29.2 & $20.5-38.5$ & 7.0 & $4.2-10.6$ & 13.4 & 8.9 & 20.4 & $15.9-25.2$ \\
\hline 165 & $98-220$ & .030 & $.024-.036$ & .058 & $.047-.074$ & 10.6 & $9.0-12.4$ & 21.0 & $17.2-25.5$ & 4.6 & $3.4-5.1$ & 16.3 & $9.7-22.9$ & 20.9 & $14.4-28.0$ \\
\hline 272 & $209-336$ & .037 & $.029-.044$ & .081 & $.069-.094$ & 20.7 & $15.6-28.0$ & 44.2 & $38.6-51.0$ & 11.4 & $10.9-12.1$ & 8.2 & $4.6-13.6$ & 20.8 & $16.7-28.4$ \\
\hline 138 & $125-160$ & .051 & $.036-.062$ & .085 & $.076-.090$ & 51.5 & $23.4-69.6$ & 82.6 & $48.2-103.2$ & 4.7 & $3.6-5.4$ & 4.7 & $2.6-8.0$ & 9.4 & $6.2-13.0$ \\
\hline 196 & $143-250$ & .036 & $.034-.038$ & .091 & $.076-.106$ & 16.0 & $10.0-22.0$ & 44.1 & $41.2-47.0$ & 12.4 & $5.4-19.4$ & 8.5 & $2.4-14.6$ & 21.1 & $8.3-34.0$ \\
\hline 188 & $153-221$ & .048 & $.041-.055$ & .088 & $.068-.108$ & 39.2 & $31.7-46.7$ & 67.9 & $52.7-83.0$ & 7.5 & $3.8-11.2$ & 2.1 & $1.1-3.1$ & 9.6 & $7.1-12.1$ \\
\hline 262 & 214-336 & .032 & $.024-.044$ & .069 & $.042-.094$ & 16.2 & $10.0-28.0$ & 35.0 & $20.5-54.7$ & 9.7 & $6.0-13.1$ & 10.8 & $2.0-19.0$ & 20.5 & $8.4-26.2$ \\
\hline 283 & $189-424$ & .042 & $.028-.052$ & .081 & $.066-.108$ & 21.9 & 11.129 .0 & 43.6 & $32.2-60.0$ & 11.0 & $4.5-29.5$ & 33.4 & $14.6-44.5$ & 44.4 & $25.0-58.7$ \\
\hline 227 & $202-270$ & .029 & $.020-.042$ & .058 & $.050-.064$ & 28.2 & $19.5-39.5$ & 55.2 & $48.0-60.0$ & 6.6 & $5.9-7.1$ & 0.7 & $0.3-1.4$ & 7.3 & $6.2-8.5$ \\
\hline 247 & $196-314$ & .038 & $.014-.056$ & .073 & $.046-.086$ & 34.0 & $11.5-57.7$ & 63.1 & $37.0-78.3$ & 8.6 & $4.3-13.2$ & 0.2 & $0.0-0.5$ & 8.8 & $4.4-13.2$ \\
\hline 258 & $196-295$ & .034 & $.031-.036$ & .062 & $.058-.071$ & 22.8 & $13.8-24.7$ & 36.8 & $31.6-40.0$ & 6.8 & $6.2-7.7$ & 31.7 & $26.8-35.3$ & 38.5 & $33.2-41.5$ \\
\hline 224 & $178-265$ & .055 & $.041-.078$ & .089 & $.074-.098$ & 31.4 & $20.7-49.0$ & 49.6 & $43.2-61.2$ & 7.6 & $5.2-8.9$ & 44.0 & $38.7-47.2$ & 51.6 & $44.0-55.0$ \\
\hline 347 & $208-606$ & .038 & $.029-.044$ & .086 & $.070-.094$ & 20.0 & $15.7-28.0$ & 42.4 & $38.6-51.0$ & 16.6 & $12.0-25.3$ & 14.6 & $4.6-27.7$ & 31.2 & $17.0-48.0$ \\
\hline 330 & $209-678$ & .030 & $.024-.040$ & .062 & $.042-.076$ & 15.3 & $9.0-21.5$ & 31.9 & $20.5-38.5$ & 10.6 & $5.0-19.2$ & 19.8 & $9.6-39.0$ & 30.4 & $17.0-58.7$ \\
\hline
\end{tabular}

ably less than that observed in both respiratory and Tris alkalosis. The infusion of bicarbonate produces less change in cellular $\mathrm{pH}$ than the infusion of Tris or the induction of respiratory alkalosis (22).

In all experiments other than those in acute and chronic metabolic alkalosis, two-thirds isotonic sodium sulfate was infused at a rate of $5 \mathrm{ml}$ per minute to insure acidification of the urine (23). The experiments summarized at the bottom of Table VI were performed to determine the influence of the infusion of sulfate on the renal responses described above. During the control phase of three of these experiments, animals without prior treatment were infused with isotonic sodium chloride. In the other two, ammonium chloride had been given on the day preceding the experiment. Thus the degree of acidosis was less in these experiments than in those grouped as chronic metabolic acidosis. The infusion was then changed to two-thirds isotonic sodium sulfate, and a priming dose of sulfate was given. The change to the sulfate infusion caused the expected drop in urine $\mathrm{pH}$ (from 6.59 to 6.04 ) and increase in ammonia excretion (from 14.6 to $19.8 \mu$ moles per minute). Since ammonia production remained ments. Accordingly control values had to be obtained in experiments on animals in normal acid-base balance. unchanged, the rate of addition of ammonia to renal venous blood decreased as did the renal venous (cellular) $\mathrm{PNH}_{3}$. Thus the diversion of ammonia from blood to urine without change in rate of production was associated with a fall in cellular $\mathrm{PNH}_{3}$, not unlike that seen in acute metabolic acidosis.

\section{Discussion}

The concept that diffusion equilibrium for ammonia is attained between tubular cells and renal venous blood is strongly suggested by the data presented in Tables I and II and Figures 1 and 2 and by the argument outlined in the text. This view is further supported by the observation of Balagura and Pitts (24) that ammonia diffuses rapidly in both directions across the renal tubular epithelium, the direction being determined by the $\mathrm{pH}$ gradient, a concept recently confirmed by Cannessa-Fischer and associates (25) and Sullivan and McVaugh (26). Certainly less firmly established is the view that the renal venous $\mathrm{PNH}_{3}$ is a fair approximation of the $\mathrm{PNH}_{3}$ of cortical tubular cells. In reality, the $\mathrm{PNH}_{3}$ of the mixed renal venous blood must be a function of rates of flow, $\mathrm{pH}$, and $\mathrm{PNH}_{3}$ values of the several blood streams derived from cortex, medulla, and papilla. Only if the cortical flow constitutes the 


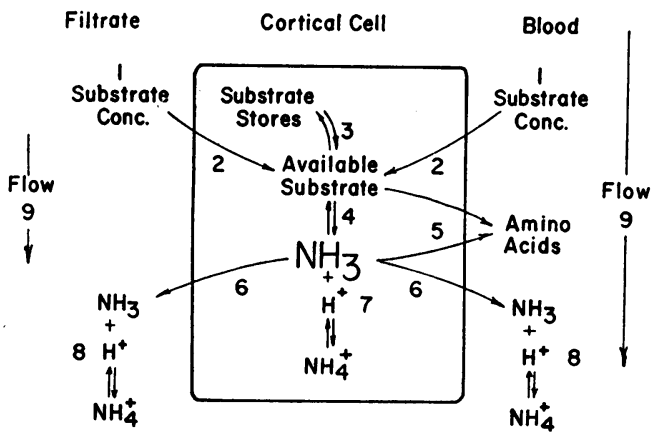

Fig. 5. FACTORS AFFECTING CONCENTRATION OF FREE BASE AMMONIA $\left(\mathrm{PNH}_{3}\right)$ OF TUBULAR CELLS.

major fraction of the total venous outflow and if the $\mathrm{pH}$ and $\mathrm{PNH}_{3}$ values of other contributing vascular streams are not too different, can the renal venous $\mathrm{PNH}_{3}$ be considered a fair approximation of cortical cell $\mathrm{PNH}_{3}$. We have tacitly made this assumption but recognize it as an assumption. It is probable, however, that our further studies of renal venous $\mathrm{PNH}_{3}$ under a variety of conditions have significance even if the values observed represent only the mean of widely differing cellular values.

The concentration of free base ammonia or, expressed differently, the $\mathrm{PNH}_{3}$ of tubular cells ultimately depends on the balance between rate of cellular production of ammonia and rate of diffusion of ammonia from cells into tubular urine and peritubular blood. Both production and rate of diffusion are conditioned by a number of factors, the more significant of which are summarized in Figure 5. The numbers of the paragraph headings below are intended to direct attention to the appropriate parts of Figure 5.

1. Although increased substrate (glutamine) concentration in chronic metabolic acidosis may or may not be a significant factor in the control of rate of ammonia production (2), there is no doubt that elevation of plasma level by the infusion of glutamine very significantly increases the rate of excretion (27) and of production of ammonia and $\mathrm{PNH}_{3}$ of tubular cells.

2. The transport of glutamine into tubular cells both from filtrate and from peritubular blood is an active, energy-consuming process (3). The extraction of glutamine from blood perfusing the kidney is reduced in metabolic alkalosis in comparison with that observed in metabolic acidosis (3). Therefore, the acid-base state influences the transport mechanism. How the influence is exerted is uncertain.

3. Whether all intracellular substrate is available for ammonia production or whether a portion is segregated in stores that are relatively inert metabolically is unknown.

4. Glutamine can give rise to ammonia in several ways: $a$ ) the amide nitrogen can be hydrolytically split to form ammonia and glutamate by a phosphate activated glutaminase. $b$ ) The $\alpha$-amino nitrogen of glutamine can be transferred to pyruvate or other keto acids to form a new amino acid and $\alpha$-ketoglutaramate by glutamine transaminase. The amide nitrogen of $\alpha$-ketoglutaramate is subsequently split hydrolytically by an amidase to form ammonia and $\alpha$-ketoglutarate. c) The glutamate formed in reaction $\alpha$ can be transformed to $\alpha$-ketoglutarate and ammonia by glutamic dehydrogenase in the presence of diphosphopyridine nucleotide. $d$ ) The glutamate can also enter into transamination reactions with keto acids to form other amino acids and $\alpha$-ketoglutarate (28, 29). Which of these reactions is the more significant in vivo is uncertain, although all can be demonstrated in vitro. The infusion of Tris or sodium bicarbonate and the induction of respiratory alkalosis markedly reduce the production of ammonia. However, because diffusion of ammonia into alkaline urine does not occur, cellular $\mathrm{PNH}_{3}$ increases. Whether reduced ammonia production is the result of reduced transport of substrate into tubule cells or an affect of cell $\mathrm{pH}$ or cell $\mathrm{PNH}_{3}$ on enzyme activity is uncertain. Equally uncertain is the nature of adaptation of ammonia production in chronic acidosis in the dog (7), in which species enzyme adaptation does not occur (30). In the rat, chronic acidosis results in increased activity of ammonia-producing enzymes (31), including both glutaminase and glutamine transaminase.

5. The kidney normally produces alanine and serine $(3,5)$ probably by transamination and possibly by reductive amination also. Such reactions divert nitrogen from ammonia formation to amino acid formation, hence reduce $\mathrm{PNH}_{3}$. How these reactions are regulated is unknown.

$6,7,8$. The rate of diffusion of ammonia from cells into blood and tubular urine is determined ultimately by the $\mathrm{PNH}_{3}$ of the three phases. The greater the hydrogen ion concentration of tubular 
urine, the lower the $\mathrm{PNH}_{3}$ relative to that of the cell and the greater the diffusion gradient from cell to tubular urine. If the $\mathrm{pH}$ of the urine is high, the diffusion gradient may be reversed and the preformed ammonia that enters the tubule in the filtrate may diffuse back into peritubular blood along with that produced in cells (24). The greater cellular $\mathrm{PNH}_{3}$ in respiratory and Tris alkalosis in comparison with that induced by the infusion of bicarbonate may be a consequence of greater intracellular alkalinity.

9. Although it is probable that the $\mathrm{pH}$ of the peritubular blood under all circumstances is considerably higher than that of tubular cells, the high volume flow of blood permits the removal of significant amounts of ammonia in the renal venous effluent. According to Rector and Orloff (30), the volume flow of urine may be a limiting factor in the excretion of ammonia if urine $\mathrm{pH}$ is above 6.0 to 6.5 .

\section{Summary}

Under most circumstances, the $\mathrm{PNH}_{3}$ and the concentration of ammonia in renal venous blood are greater than in arterial blood. Thus ammonia diffuses as the free base from its site of production in renal tubular cells not only into acid urine, where it is trapped as ammonium ion, but also into the blood perfusing the kidney. When the arterial concentration of ammonia is raised significantly by the infusion of ammonium lactate, the diffusion gradient is reversed and ammonia diffuses from peritubular capillaries into tubular cells and into acid urine. Under such circumstances, the $\mathrm{PNH}_{3}$ and the concentration of ammonia in renal venous blood are less than in arterial blood. By interpolation, a $\mathrm{PNH}_{3}$ can be found such that ammonia neither diffuses from cells into peritubular blood nor from peritubular blood into cells, i.e., the renal venous $\mathrm{PNH}_{3}$ is exactly equal to the arterial $\mathrm{PNH}_{3}$. The renal venous $\mathrm{PNH}_{3}$ must also equal cellular $\mathrm{PNH}_{3}$, for the cells neither give up ammonia to the peritubular blood nor receive ammonia from it. Since the $\mathrm{PNH}_{3}$ of renal venous blood under such circumstances differs only slightly from that which exists under normal conditions, it is probable that diffusion equilibrium exists at all times between tubular cells and peritubular blood. Ac- cordingly the $\mathrm{PNH}_{3}$ of renal venous blood can be employed as an approximate measure of cellular $\mathrm{PNH}_{3}$. Because cortical blood flow constitutes about $90 \%$ of total renal blood flow, it is probable that the $\mathrm{PNH}_{3}$ of renal venous blood largely represents that of cortical structures, namely cells of proximal and distal convoluted tubules.

Using renal venous $\mathrm{PNH}_{3}$ as a measure of cellular $\mathrm{PNH}_{3}$, we have observed that in acute respiratory and acute metabolic acidosis, renal production of ammonia is unchanged, cellular $\mathrm{PNH}_{3}$ is reduced, and a portion of the ammonia usually added to renal venous blood is now excreted in more acid urine. In acute metabolic alkalosis, induced by the infusion of sodium bicarbonate or Tris, and in acute respiratory alkalosis, induced by hyperventilation, renal production of ammonia is markedly reduced, cellular $\mathrm{PNH}_{3}$ is greatly increased, and most of the ammonia usually excreted in the urine now diffuses into renal venous blood. In chronic metabolic acidosis, renal production of ammonia is markedly increased, cellular $\mathrm{PNH}_{3}$ is only slightly increased, and most of the excess ammonia formed diffuses into the acid urine. When the plasma concentration of glutamine is raised by intravenous infusion, renal production of ammonia is increased moderately, cellular $\mathrm{PNH}_{3}$ is increased modestly, and most of the excess ammonia formed diffuses into the acid urine. The infusion of sodium sulfate does not alter renal production of ammonia, but because it lowers urine $\mathrm{pH}$, a part of the ammonia that ordinarily would diffuse into renal blood is now excreted in the urine. Cellular $\mathrm{PNH}_{3}$ decreases.

\section{References}

1. Nash, T. P., Jr., and S. R. Benedict. The ammonia content of the blood, and its bearing on the mechanism of acid neutralization in the animal organism. J. biol. Chem. 1921, 48, 463.

2. Van Slyke, D. D., R. A. Phillips, P. B. Hamilton, R. M. Archibald, P. H. Futcher, and A. Hiller. Glutamine as source material of urinary ammonia. J. biol. Chem. 1943, 150, 481.

3. Shalhoub, R., W. Webber, S. Glabman, M. CanessaFischer, J. Klein, J. DEHaas, and R. F. Pitts. Extraction of amino acids from and their addition to renal blood plasma. Amer. J. Physiol. 1963, 204, 181.

4. Pitts, R. F., J. DEHaas, and J. Klein. Relation of renal amino and amide nitrogen extraction to am- 
monia production. Amer. J. Physiol. 1963, 204, 187.

5. Owen, E. E., and R. R. Robinson. Amino acid extraction and ammonia metabolism by the human kidney during the prolonged administration of ammonium chloride. J. clin. Invest. 1963, 42, 263.

6. Briggs, A. P. Functional activity of renal epithelium in certain types of nephritis as indicated by the secretion of ammonia. Arch. intern. Med. 1937, 60, 193.

7. Pitts, R. F. Renal excretion of acid. Fed. Proc. 1948, 7, 418.

8. Orloff, J., and R. W. Berliner. The mechanism of the excretion of ammonia in the dog. J. clin. Invest. 1956, 35, 223.

9. Milne, M. D., B. H. Scribner, and M. A. Crawford. Non-ionic diffusion and the excretion of weak acids and bases. Amer. J. Med. 1958, 24, 709.

10. Owen, E. E., J. H. Johnson, and M. P. Tyor. The effect of induced hyperammonemia on renal ammonia metabolism. J. clin. Invest. 1961, 40, 215.

11. Pitts, R. F. Unpublished observation.

12. Jacquez, J. A., J. W. Poppell, and R. Jeltsch. Solubility of ammonia in human plasma. J. appl. Physiol. 1959, 14, 255.

13. Bromberg, P. A., E. D. Robin, and C. E. Forkner, $\mathrm{Jr}$. The existence of ammonia in blood in vivo with observations on the significance of the $\mathrm{NH}_{4}^{+}-$ $\mathrm{NH}_{3}$ system. J. clin. Invest. 1960, 39, 332.

14. Archibald, R. M. Quantitative microdetermination of ammonia in the presence of glutamine and other labile substances. J. biol. Chem. 1943, 151, 141.

15. Phillips, R. A. in Quantitative Clinical Chemistry Methods (Army ed.), J. P. Peters and D. D. Van Slyke, Eds. Baltimore, Williams and Wilkins, 1944, vol. 2.

16. Bratton, A. C., and E. K. Marshall, Jr. A new coupling component for sulfanilamide determination. J. biol. Chem. 1939, 128, 537.

17. Van Slyke, D. D., and J. M. Neill. The determination of gases in blood and other solutions by vacuum extraction and manometric measurement. I. J. biol. Chem. 1924, 61, 523.
18. Wolf, A. V. Total renal blood flow at any urine flow or extraction fraction. Amer. J. Physiol. 1941, 133, 496.

19. Conway, E. J. Microdiffusion Analysis and Volumetric Error. London, Lockwood, 1958.

20. Kramer, K., D. Thurau, and P. Deetjen. Hamodynamik des Nierenmarks. Pflügers Arch. ges. Physiol. 1960, 270, 251.

21. Glabman, S., R. M. Klose, and G. Giebisch. Micropuncture study of ammonia excretion in the rat. Amer. J. Physiol. 1963, 205, 127.

22. Caldwell, P. C. Intracellular pH. Int. Rev. Cytol. 1956, 5, p. 229.

23. Lauson, H. D., and D. D. Thompson. Effects in dogs of decrease in glomerular filtration rate on cation excretion during intravenous administration of unreabsorbable anions. Amer. J. Physiol. 1958, 192, 198

24. Balagura, S., and R. F. Pitts. Excretion of ammonia injected into renal artery. Amer. J. Physiol. 1962, 203, 11.

25. Canessa-Fischer, M., R. Shalhoub, S. Glabman, J. DEHaas, and R. F. Pitts. Effects of infusions of ammonia, amides, and amino acids on excretion of ammonia. Amer. J. Physiol. 1963, 204, 192.

26. Sullivan, L. P., and M. McVaugh. Effect of rapid and transitory changes in blood and urine $\mathrm{pH}$ on $\mathrm{NH}_{4}$ excretion. Amer. J. Physiol. 1963, 204, 1077.

27. Lotspeich, W. D. Metabolic Aspects of Renal Function. Springfield, Ill., Charles C Thomas, 1959.

28. Meister, A. Enzymatic transfer of alpha-amino groups. Science 1954, 120, 43.

29. Meister, A. Metabolism of glutamine. Physiol. Rev. 1956, 36, 103.

30. Rector, F. C., Jr., and J. Orloff. The effect of the administration of sodium bicarbonate and ammonium chloride on the excretion and production of ammonia. The absence of alterations in the activity of renal ammonia-producing enzymes in the dog. J. clin. Invest. 1959, 38, 366.

31. Rector, F. C., Jr., D. W. Seldin, and J. H. Copenhaver. The mechanism of ammonia excretion during ammonium chloride acidosis. $\mathrm{J}$. clin. Invest. 1955, 34, 20.

\section{SPECIAL NOTICE TO SUBSCRIBERS}

Post Offices will no longer forward the Journal when you move.

Please notify The Journal of Clinical Investigation, Business Office, 10 Stoughton Street, Boston 18, Mass., at once when you have a change of address, and do not omit the Zip Code number if there is one. 